\title{
HUBUNGAN ANTARA BUDAYA ORGANISASI DAN KOMPETENSI PEDAGOGIK DENGAN KEINOVATIFAN GURU
}

\author{
Rita Marliana ${ }^{1}$, Yossa Istiadi $^{2}$, Eka Suhardi $^{2}$ \\ ${ }^{1}$ Guru SDSN Perjuangan Terpadu, Depok, Jawa Barat \\ ${ }^{2}$ Program Pascasarjana Universitas Pakuan, \\ Email: pasca@unpak.ac.id
}

\begin{abstract}
The objective of this research is to analyse the correlation between organizational culture and pedagogic competence with innovation of civil servant teachers. The design of this study was survey and correlational approach. The research applies survey method to collect the data and correlational approach, the research that is designed to get the information about the correlation between variabel in the population. The population in this research is all civil servant teachers in state elementary school se-gugus 6 Pancoranmas district, Depok city totally 120 teachers. This research applied proportional random sampling design which determine a sample taken from a representative of each of the existing schools in the population whose numbers were adjusted by the amount of each allocation formula, using proportional random sampling using the formula with the total sample slovin as many as 93 teachers. The research revealed that there is positive and highly significant relationship between the organizational culture with teachers' innovation. There are positive and highly significant relationship between pedagogic competence and teachers' innovation.
\end{abstract}

Keywords: Organizational Culture, Paedagogic Competence, Innovation

\begin{abstract}
ABSTRAK
Penelitian ini bertujuan mengetahui hubungan antara budaya organisasi dan kompetensi pedagogik secara bersama-sama dengan inovasi guru. Penelitian ini menggunakan metode survei dengan pendekatan korelasional. Metode penelitian yang digunakan adalah metode survei untuk mengumpulkan data yang dibutuhkan, dengan pendekatan korelasional, yaitu jenis penelitian yang dirancang untuk mendapatkan informasi tentang hubungan antara setiap variabel dalam suatu populasi. Populasi dalam penelitian ini adalah seluruh Guru PNS di SD Negeri se-Gugus 6 Kecamatan Pancoranmas Kota Depok yang berjumlah 120 orang guru. Teknik pengambilan sampel dalam penelitian ini adalah proportional random sampling, yaitu menentukan sampel diambil dari perwakilan tiap-tiap sekolah yang ada dalam populasi yang jumlahnya disesuaikan dengan jumlah masing-masing, dengan menggunakan rumus alokasi proportional random sampling dengan menggunakan rumus Slovin dengan jumlah sampel sebanyak 93 orang guru. Penelitian ini menghasilkan kesimpulan sebagai berikut: Terdapat hubungan positif dan sangat signifikan antara budaya organisasi dengan inovasi guru. Terdapat hubungan positif dan sangat signifikan antara kompetensi pedagogik dengan inovasi guru. Terdapat hubungan positif dan sangat signifikan antara Budaya Organisasi dan Kompetensi Pedagogik secara bersama-sama dengan Inovasi Guru.
\end{abstract}

Kata Kunci : Komitmen terhadap Profesi, Motivasi Berprestasi, Keinovatifan. 


\section{PENDAHULUAN}

Pendidikan merupakan penghasil sumber daya manusia jangka panjang yang tidak ternilai harganya bagi kelangsungan peradaban manusia. Maka tidak mengherankan jika pendidikan menjadi hal yang diutamakan hampir di semua negara beranggapan pendidikan sebagai sesuatu hal yang penting dan prioritas utama dalam konteks pembangunan bangsa. Guru dalam konteks pendidikan mempunyai peran andil yang sangat besar dan penting dalam menciptakan generasi penerus bangsa yang unggul. Guru berperan sebagai salah satu bagian dari komponen utama dalam pendidikan. Gurulah yang berada di barisan terdepan dalam proses pelaksanaan kegiatan pendidikan berlangsung. Guru pulalah yang berhadapan langsung dengan peserta didik untuk menstransfer ilmu pengetahuan sekaligus bertugas sebagai pendidik dengan menerapkan nilai-nilai positif melalui bimbingan dan keteladanan yang dicontohkan seorang guru.

Menghadapi perubahan era globalisasi yang sangat cepat. Menuntut guru untuk berkembang dan guru mempunyai tugas dan misi yang berat. Sudah selayaknya guru memiliki inovasi dalam melaksanakan tugasnya sebagai pendidik. inovasi yang dilakukan oleh seorang guru dalam melaksanakan kegiatan pembelajaran, sangat mempengaruhi kualitas hasil pembelajaran yang diterima oleh peserta didik. Guru yang inovatif akan membuat terobosan - terobosan baru dalam meningkatkan kualitas hasil belajar peserta didik. Seperti menciptakan atau membuat strategi-strategi baru dalam melaksanakan tugasnya. Hal ini bisa dilakukan melalui media-media tertentu yang disesuaikan dengan kebutuhan, ataupun melalui memanfaatkan kecanggihan teknologi, sehingga dapat membantu mempermudah pekerjaan dan tugas - tugas seorang guru sebagai pendidik. Kegiatan pembelajaran pun akan terlaksana dengan menarik dan tidak membosankan untuk peserta didik. Hal ini membuat tujuan pembelajaran dapat terlaksana dengan efisien.

Mencermati hal ini lebih lanjut kegiatan pembelajaran di sekolah masih ada guru yang menggunakan metode pembelajaran dengan cara lama yaitu metode belajar satu arah yang berpusat pada guru. Kemajuan zaman diera globalisasi yang sudah sangat pesat alangkah baiknya pembelajaran seperti ini sudah tidak dilakukan. Model pembelajaran seperti ini membuat peserta didik menjadi tidak tertantang dan pasif. Padahal yang diharapkan adalah adanya partisipasi aktif peserta didik dalam kegiatan pembelajaran.

Berdasarkan pembatasan masalah di atas, maka permasalahan penelitian dapat dirumuskan sebagai berikut: (1). Apakah terdapat hubungan antara budaya organisasi dengan inovasi guru? (2). Apakah terdapat hubungan antara kompetensi pedagogik dengan inovasi guru? (3). Apakah terdapat hubungan antara budaya organisasi dan kompetensi pedagogik secara bersama-sama dengan inovasi guru?

\section{Inovasi Guru}

Calantone (2002:112) menyatakan bahwa inovasi (innovation) diartikan sebagai upaya dan tindakan dalam bentuk pengembangan sesuatu (product and process) untuk menjadi lebih baik atau bentuk pengembangan sesuatu yang baru dan bermanfaat bagi pengguna. Adapun istilah inovasi (innovation) diartikan sebagai taraf (degree) inovasi yang dilakukan individu.

Jones (2012: 24-25) menyatakan bahwa inovasi adalah aktivitas organisasi untuk membuat barang-barang baru atau yang ditingkatkan dan jasa atau perbaikan dalam produksi, yang terdiri dari indikator a) Inovasi Barang/Produk adalah suatu aktivitas yang berusaha memberikan solusi terhadap permasalahan yang ada, b) Inovasi dalam layanan fokus pada membuat perubahan ke lini produk dalam rangka untuk menarik perhatian lebih dari konsumen, dan c) Inovasi dalam metode adalah cara seseorang atau organisasi dalam memproduksi suatu jasa atau produk. 
Bien (2014:342) menyatakan bahwa inovasi adalah kegiatan menciptakan ide-ide baru dan menempatkan mereka dalam praktek. Di sini inovasi sebagai produk dan proses yang terdiri dari indikator a) Inovasi proses (Process Innovation) adalah tindakan dan/atau hasil dari pengembangan penggunaan/mobilisasi pengetahuan, keterampilan dan b) Inovasi produk (Product Innovation) suatu aktivitas yang berusaha memberikan solusi terhadap permasalahan yang ada.

Timothy (2013:626) menyatakan bahwa inovasi adalah ide baru diterapkan untuk memulai atau meningkatkan produk, proses, dan layanan yang memiliki indikator a) Product (Produk) adalah suatu tindakan yang berusaha memberikan solusi terhadap permasalahan yang ada, b) Process (Proses) adalah aktivitas dan/atau hasil dari pengembangan penggunaan/mobilisasi pengetahuan, keterampilan, dan c) Services (Layanan) adalah membuat perubahan ke lini produk dalam rangka untuk menarik perhatian lebih dari konsumen. Rekha (2006:108) menyatakan bahwa inovasi adalah suatu ide, gagasan, praktek atau objek/benda yang disadari dan diterima sebagai suatu hal yang baru oleh seseorang atau kelompok untuk diadopsi.

Berdasarkan konsep-konsep tersebut di atas dapat disintesiskan bahwa inovasi guru adalah tindakan untuk menghasilkan ide baru, cara-cara ataupun obyek yang dipersepsikan oleh guru sebagai sesuatu yang baru untuk memulai atau meningkatkan produk, proses, dan layanan dalam pembelajaran yang terdiri dari indikator a) ide-ide baru, b) program baru, c) layanan, d) metode baru, e) kreasi baru, f) aplikasi baru.

\section{Budaya Organisasi}

Mangkuprawira (2007:97) menyatakan bahwa budaya organisasi adalah sistem nilai, persepsi, perilaku dan keyakinan yang dianut oleh tiap individu pegawai dan kelompok pegawai tentang makna kerja dan refleksinya dalam kegiatan mencapai tujuan organisasi dan individual. Brown (2008:90) mengatakan bahwa budaya organisasi penting dikembangkan karena dampak positifnya terhadap pencapaian perubahan berkelanjutan di tempat kerja termasuk peningkatan produktivitas (kinerja). Wibowo (2011:19) menyatakan bahwa penerapan budaya dalam organisasi disebut dengan budaya organisasi.

Banyak pakar yang mengartikan budaya organisasi umumnya bersumber pada pandangan. Edgar (2008) menyatakan bahwa budaya organisasi merupakan folosofi yang mendasari kebijakan organisasi, aturan main untuk bergaul, dan perasaan atau iklim yang dibawa oleh persiapan fisik organisasi. Adapun pengertian budaya organisasi adalah filosofi dasar organisasi yang memuat keyakinan, norma-norma, dan nilai-nilai bersama yang menjadi karakteristik inti tentang bagaimana cara melakukan sesuatu dalam organisasi. Keyakinan, norma-norma, dan nilai-nilai tersebut menjadi pegangan pada sumber daya manusia dalam organisasi dalam melaksanakan kinerjanya.

Yukl (2002:108) menyatakan bahwa the term organizational culture is used to describe the shared values and beliefs of members about the activities of the organization and interpersonal relationships. Budaya organisasi adalah nilai-nilai dan keyakinan anggota organisasi dalam melakukan pekerjaan dan melakukan hubungan interpersonal. Ernawan (2007:99) menyatakan bahwa budaya organisasi merupakan gaya dan cara hidup dari suatu organisasi yang merupakan pencerminan dari nilai-nilai atau kepercayaan yang selama ini dianut oleh seluruh anggota organisasi.

Dari uraian di atas dapat disintesiskan bahwa budaya organisasi adalah seperangkat nilai-nilai dan norma-norma, pola asumsi dasar, sistem makna bersama, yang melaksanakan cara pandang, persepsi, kerjasama dan keterbukaan dengan organisasi. Adapun indikatornya adalah: a) pengambilan resiko, b) integritas, c) penghormatan terhadap orang, d) hubungan antar individu, e) keterbukaan, f) orientasi hasil, g) kerjasama. 


\section{Kompetensi Pedagogik}

Sopiatin, (2010: 67) menyatakan bahwa kompetensi pedagogik adalah kemampuan guru dalam mengelola pembelajaran peserta didik, meliputi merancang pembelajaran, melaksanakan pembelajaran, merancang dan melaksanakan evaluasi, mengembangkan siswa untuk mengaktualisasikan berbagai potensinya, serta memahami siswa secara mendalam. Kompetensi guru dapat berpengaruh terhadap mutu proses belajar mengajar, namun persepsi siswa terhadap kompetensi yang dimiliki guru mempengaruhi proses belajar siswa. Thalib, (2010: 275) menyatakan bahwa kompetensi pedagogik meliputi pemahaman terhadap peserta didik, perancangan dan pelaksanaan proses pembelajaran, evaluasi hasil pembelajaran, dan pengembangan potensi peserta didik dengan indikator esensia, memahami peserta didik, memahami landasan pendidikan, menata pembelajaran dan melaksanakan pembelajaran, merancang dan melaksanakan evaluasi, pengembangan terhadap berbagai potensi.

Muhith (2008: 148) menyatakan bahwa kompetensi pedagogik adalah seperangkat kemampuan dan keterampilan yang berkaitan dengan interaksi belajar mengajar antara guru dengan siswa dalam kelas. Kompetensi pedagogik meliputi kemampuan guru dalam menjelaskan matri, melaksanakan metode pembelajaran, memberikan pertanyaan, menjawab pertanyaan, mengelola kelas dan melakukan evaluasi. Mulyasa (2007: 75) menyatakan bahwa kompetensi pedagogik adalah kemampuan guru dalam mengelola pembelajaran peserta didik yang meliputi pemahaman terhadap peserta didik, perancangan dan pelaksanaan pembelajaran, evaluasi dan hasil belajar, pengembangan peserta didik, untuk mengaktualisasikan berbagai potensi yang dimiliki.

Berdasarkan teori-teori di atas dapat disintesiskan bahwa kompetensi pedagogik adalah kemampuan yang dimiliki guru yang berkaitan dengan teori pembelajaran dan pengelolaan pembelajaran dalam rangka memberi pembelajaran kepada peserta didik untuk mencapai kedewasaan kognitif, afektif dan psikomotorik. Adapun indikatornya adalah a) Merancang program pembelajaran, b) Merencanakan program pembelajaran, c) Mengembangkan program pembelajaran, d) Mengelola pelaksanaan program pembelajaran, e) Menilai proses dan hasil pembelajaran dan f) Menganalisis faktor yang mempengaruhi keberhasilan proses pembelajaran.

\section{METODE PENELITIAN}

Metode penelitian yang digunakan adalah metode survei untuk mengumpulkan data yang dibutuhkan, dengan pendekatan korelasional, yaitu jenis penelitian yang dirancang untuk mendapatkan informasi tentang hubungan antara setiap variabel dalam suatu populasi. Penelitian ini melibatkan dua macam karakteristik variabel, yaitu variabel terikat dan variabel bebas. Variabel- variabel tersebut adalah variabel terikat yakni Inovasi Guru (Y), serta dua variabel bebas yakni Budaya Organisasi $\left(\mathrm{X}_{1}\right)$, dan Kompetensi Pedagogik $\left(\mathrm{X}_{2}\right)$. Populasi dalam penelitian ini adalah seluruh Guru PNS di SD Negeri se-Gugus 6 Kecamatan Pancoranmas Kota Depok yang berjumlah 120 orang guru. Teknik pengambilan sampel dalam penelitian ini adalah proportional random sampling, yaitu menentukan sampel diambil dari perwakilan tiap-tiap sekolah yang ada dalam populasi yang jumlahnya disesuaikan dengan jumlah masing-masing, dengan menggunakan rumus alokasi proportional random sampling dengan menggunakan rumus Slovin. Jumlah sampel yang digunakan dalam penelitian sebanyak 93 orang guru. Data penelitian yang sudah terkumpul akan dianalisis secara statistik deskriptif dan secara statistik inferensial. 


\section{HASIL PENELITIAN}

\section{Pengujian Persyaratan Analisis}

\section{Uji Normalitas}

Dari hasil perhitungan uji normalitas galat baku taksiran $\left(\mathrm{Y}-\hat{\mathrm{Y}}_{1}\right)$ persamaan regresi antara variabel Budaya Organisasi $\left(\mathrm{X}_{1}\right)$ dengan variabel Inovasi Guru $(\mathrm{Y})$ dengan persamaan regresi yang diperoleh adalah $\hat{\mathrm{Y}}=96,249+0,322 \mathrm{X}_{1}$ hal ini menunjukkan bahwa nilai tersebar dengan luas daerah ( $\mathrm{L}_{0}$ maksimal) sebesar 0,059 , sedangkan $\mathrm{L}_{\text {tabel }}$ pada $\mathrm{n}=93$ dan taraf signifikansi $\alpha=0,05$ sebesar 0,092 Kriteria persyaratan galat baku $\left(\mathrm{Y}-\hat{\mathrm{Y}}_{1}\right)$ berdistribusi normal jika $\mathrm{L}_{0}<\mathrm{L}_{\mathrm{t}}$ maka galat baku antara variabel Budaya Organisasi $\left(\mathrm{X}_{1}\right)$ dengan variabel Inovasi Guru (Y) dapat dikatakan berasal dari populasi berdistribusi normal, hal ini disebabkan karena $\mathrm{L}_{0}$ sebesar $0,059<\mathrm{L}_{\mathrm{t}}$ sebesar 0,092.

\begin{tabular}{cccc}
\multicolumn{4}{c}{ Hasil Uji Normalitas Data Y atas $\mathrm{X}_{1}$} \\
\hline Galat & $\mathbf{L}_{\text {hitung }}$ & $\mathbf{L}_{\text {tabel }}$ & Kesimpulan \\
\hline $\mathrm{Y}-\hat{\mathrm{Y}}$ & 0,059 & 0,092 & $\begin{array}{c}\text { Berdistribusi } \\
\text { Normal }\end{array}$ \\
\hline \multicolumn{4}{c}{} \\
\hline
\end{tabular}

Dari hasil perhitungan uji normalitas galat baku taksiran $\left(\mathrm{Y}-\hat{\mathrm{Y}}_{2}\right)$ persamaan regresi antara variabel Kompetensi Pedagogik $\left(\mathrm{X}_{2}\right)$ dengan variabel Inovasi Guru (Y) dengan persamaan regresi yang diperoleh adalah $\hat{\mathrm{Y}}=146,719+0,032 \mathrm{X}_{2}$ hal ini menunjukkan bahwa nilai tersebar dengan luas daerah ( $\mathrm{L}_{0}$ maksimal) sebesar 0,075 , sedangkan $\mathrm{L}_{\text {tabel }}$ pada $\mathrm{n}$ $=93$ dan taraf signifikansi $\alpha=0,05$ sebesar 0,092. Kriteria persyaratan galat baku $\left(\mathrm{Y}-\hat{\mathrm{Y}}_{2}\right)$ berdistribusi normal jika $\mathrm{L}_{0}<\mathrm{L}_{\mathrm{t}}$ maka galat baku taksiran antara variabel Kompetensi Pedagogik $\left(\mathrm{X}_{2}\right)$ dengan variabel Inovasi Guru $(\mathrm{Y})$ dapat dikatakan berasal dari populasi berdistribusi normal, hal ini disebabkan karena $\mathrm{L}_{0}$ sebesar $0,075<\mathrm{L}_{\mathrm{t}}$ sebesar 0,092

Hasil Uji Normalitas Data Y atas $\mathrm{X}_{2}$

\begin{tabular}{cccc}
\hline Galat & $\mathbf{L}_{\text {hitung }}$ & $\mathbf{L}_{\text {tabel }}$ & Kesimpulan \\
\hline $\mathrm{Y}-\stackrel{\Lambda}{\mathrm{Y}}$ & 0,075 & 0,092 & $\begin{array}{c}\text { Berdistribusi } \\
\text { Normal }\end{array}$ \\
\hline \multicolumn{4}{c}{} \\
\hline
\end{tabular}

\section{Uji Homogenitas}

Dari hasil perhitungan uji homogenitas varians data variabel Inovasi Guru (Y) atas variabel Budaya Organisasi $\left(\mathrm{X}_{1}\right)$ diperoleh hasil $\chi_{\text {hitung }}^{2}$ sebesar 9,67 sedangkan harga $\chi_{\text {tabel }}^{2}$

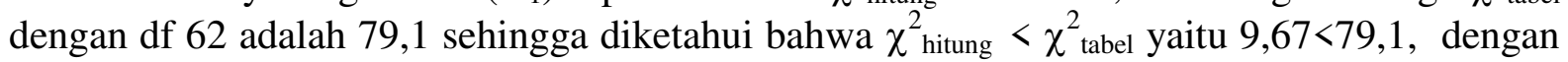
demikian dapat disimpulkan bahwa kelompok data memiliki varians yang homogen sebagaimana dapat dilihat pada tabel berikut. 
Hasil Uji Homogenitas Varians Data $\mathrm{Y}$ atas $\mathrm{X}_{1}$

\begin{tabular}{ccccc}
\hline Pengelompokan & $\mathbf{d k}$ & $\chi^{2}$ hitung & $\chi^{2}{ }_{(0,05)}$ & Kesimpulan \\
\hline $\mathrm{Y}^{2}$ atas $\mathrm{X}_{1}$ & 62 & 9,67 & 79,1 & Homogen \\
\hline \multicolumn{4}{c}{ Kriteria Homogen Jika $\chi_{\text {hitung }}^{2}<\chi_{\text {tabel }}^{2}$} \\
\hline
\end{tabular}

Dari hasil perhitungan uji homogenitas varians data variabel Inovasi Guru $(\mathrm{Y})$ atas variabel Kompetensi Pedagogik $\left(\mathrm{X}_{2}\right)$ diperoleh hasil $\chi^{2}$ hitung sebesar 21,08 sedangkan harga $\chi_{\text {tabel }}^{2}$ dengan df 79 adalah 101,9 sehingga diketahui bahwa $\chi_{\text {hitung }}^{2}<\chi_{\text {tabel yaitu }}^{2}$ $21,08<101,9$, dengan demikian dapat disimpulkan bahwa kelompok data memiliki varians yang homogen sebagaimana dapat dilihat pada tabel berikut:

Hasil Uji Homogenitas Varians Data $\mathrm{Y}$ atas $\mathrm{X}_{2}$

\begin{tabular}{ccccc}
\hline Pengelompokan & $\mathbf{d k}$ & $\chi^{2}$ hitung & $\chi_{(0,05)}^{2}$ & Kesimpulan \\
\hline $\mathrm{Y}$ atas $\mathrm{X}_{2}$ & 79 & 21,08 & 101,9 & Homogen \\
\hline \multicolumn{5}{c}{ Kriteria Homogen Jika $\chi_{\text {hitung }}^{2}<\chi_{\text {tabel }}^{2}$} \\
\hline
\end{tabular}

\section{Pengujian Hipotesis}

\section{Hubungan antara Budaya Organisasi $\left(X_{1}\right)$ dengan Inovasi Guru (Y)}

Hasil analisis regresi sederhana antara Budaya Organisasi $\left(\mathrm{X}_{1}\right)$ dengan Inovasi Guru (Y) diperoleh persamaan regresi $\hat{Y}=96,249+0,321 X_{1}$. Tingkat signifikansi dan linieritas dari persamaan regresi dapat digunakan hasil uji $F$. Kriteria pengujian jika residu nilai $F_{\text {hitung }}$ $>\mathrm{F}_{\text {tabel }}$ dengan taraf $\alpha=0,05$ maka korelasi adalah signifikan, sedangkan apabila nilai tuna cocok $F_{\text {hitung }}<\mathrm{F}_{\text {tabel }}$ pada taraf $\alpha=0,05$ maka dapat dikatakan bahwa persamaan regresi adalah linier.

Hasil perhitungan uji linier regresi diketahui nilai $\mathrm{F}_{\text {hitung }}=0,744$ dan $\mathrm{F}_{\text {tabel }}$ pada taraf $\alpha$ $=0,05$ adalah 1,63 pada taraf $\alpha=0,01$ adalah 2,00 dengan demikian diketahui bahwa $\mathrm{F}_{\text {hitung }}<$ $\mathrm{F}_{\text {tabel }}$ yaitu $(0,744<1,63)$, sehingga dapat disimpulkan bahwa persamaan regresi $\hat{\mathrm{Y}}=96,249+0,321 \mathrm{X}_{1}$ adalah linier, dimana persamaan regresi tersebut menunjukkan bahwa untuk setiap kenaikan satu unit skor variabel Budaya Organisasi $\left(\mathrm{X}_{1}\right)$ akan mengakibatkan kenaikan sebesar 0,321 unit skor variabel Inovasi Guru (Y) pada konstanta sebesar 96,249

Hasil uji signifikansi koefisien korelasi menggunakan Uji-t dengan kriteria jika $t_{\text {hitung }}>$ $\mathrm{t}_{\text {tabel }}$ maka dinyatakan sangat signifikan. Hasil perhitungan uji signifikansi koefisien korelasi menghasilkan nilai $t_{\text {hitung }}$ sebesar 8,252 dengan nilai tabel pada $\mathrm{n}=\mathrm{dk}-2(93-2=91)$ pada $\alpha=$ 0,05 sebesar 1,980 dan pada $\alpha=0,01$ sebesar 2,617. Dengan demikian diketahui bahwa $\mathrm{t}_{\text {hitung }}$ $>\mathrm{t}_{\text {tabel }}$ yaitu $(8,252>2,617)$, sehingga dapat disimpulkan bahwa koefisien korelasi variabel Budaya Organisasi $\left(\mathrm{X}_{1}\right)$ dengan variabel Inovasi Guru $(\mathrm{Y})$ dinyatakan sangat signifikan. Hal tersebut menyatakan hipotesis nol $\left(\mathrm{H}_{0}\right)$ ditolak dan hipotesis alternatif $\left(\mathrm{H}_{1}\right)$ diterima, artinya terdapat hubungan yang positif dan signifikan antara Budaya Organisasi dengan Inovasi Guru. 


\section{Hubungan Hubungan antara Kompetensi Pedagogik $\left(\mathbf{X}_{2}\right)$ dengan Inovasi Guru}

(Y)

Hasil analisis regresi sederhana antara Kompetensi Pedagogik $\left(\mathrm{X}_{2}\right)$ dengan Inovasi Guru (Y) diperoleh persamaan regresi $\hat{Y}=146,719+0,032 X_{2}$. Tingkat signifikansi dan linieritas dari persamaan regresi dapat digunakan hasil uji F. Kriteria pengujian jika residu nilai $\mathrm{F}_{\text {hitung }}>\mathrm{F}_{\text {tabel }}$ dengan taraf $\alpha=0,05$ maka korelasi adalah signifikan, sedangkan apabila nilai tuna cocok $\mathrm{F}_{\text {hitung }}<\mathrm{F}_{\text {tabel }}$ pada taraf $\alpha=0,05$ maka dapat dikatakan bahwa persamaan regresi adalah linier.

Hasil perhitungan uji linier regresi diketahui nilai $\mathrm{F}_{\text {hitung }}=0,926$ dan $\mathrm{F}_{\text {tabel }}$ pada taraf $\alpha$ $=0,05$ adalah 1,88 pada taraf $\alpha=0,01$ adalah 2,41 dengan demikian diketahui bahwa $F_{\text {hitung }}<$ $F_{\text {tabel }}$ yaitu $(0,926<1,88)$, sehingga dapat disimpulkan bahwa persamaan regresi $\hat{\mathrm{Y}}=146,719+0,032 \mathrm{X}_{2}$ adalah linier, dimana persamaan regresi tersebut menunjukkan bahwa untuk setiap kenaikan satu unit skor variabel Kompetensi Pedagogik $\left(\mathrm{X}_{2}\right)$ akan mengakibatkan kenaikan sebesar 0,032 unit skor variabel Inovasi Guru (Y) pada konstanta sebesar 146,719

Hasil uji signifikansi koefisien korelasi menggunakan Uji-t dengan kriteria jika $t_{\text {hitung }}>$ $t_{\text {tabel }}$ maka dinyatakan sangat signifikan. Hasil perhitungan uji signifikansi koefisien korelasi menghasilkan nilai $\mathrm{t}_{\text {hitung }}$ sebesar 3,238 dengan nilai $\mathrm{t}_{\text {tabel }}$ pada $\mathrm{n}=\mathrm{dk}-2(93-2=91)$ pada $\alpha=$ 0,05 sebesar 1,980 dan pada $\alpha=0,01$ sebesar 2,617. Dengan demikian diketahui bahwa $t_{\text {hitung }}$ $>\mathrm{t}_{\text {tabel }}$ yaitu $(3,238>2,617)$, sehingga dapat disimpulkan bahwa koefisien korelasi variabel Kompetensi Pedagogik $\left(\mathrm{X}_{2}\right)$ dengan variabel Inovasi Guru $(\mathrm{Y})$ dinyatakan sangat signifikan.

Hal tersebut menyatakan hipotesis nol $\left(\mathrm{H}_{0}\right)$ ditolak dan hipotesis alternatif $\left(\mathrm{H}_{1}\right)$ diterima, artinya terdapat hubungan yang positif dan signifikan antara Kompetensi Pedagogik dengan Inovasi Guru.

\section{Hubungan antara Budaya Organisasi $\left(X_{1}\right)$ dan Kompetensi Pedagogik (X2) secara bersama-sama dengan Inovasi Guru (Y)}

Hasil perhitungan dan analisis regresi linier berganda antara variabel Budaya Organisasi $\left(\mathrm{X}_{1}\right)$ dan Kompetensi Pedagogik $\left(\mathrm{X}_{2}\right)$ secara bersama-sama dengan Inovasi Guru (Y) diperoleh persamaan regresi $\hat{Y}=89,935+0,333 X_{1}+0,174 X_{2}$ Untuk mengetahui signifikansi terhadap persamaan regresi maka digunakan Uji $F$ dengan kriteria jika pada taraf $\alpha=0,05$ nilai $F_{\text {hitung }}>F_{\text {tabel }}$ dinyatakan bahwa korelasi signifikan.

Hasil menunjukkan nilai $\mathrm{F}_{\text {hitung }}$ sebesar 36,249 dan $\mathrm{F}_{\text {tabel }}$ dengan dk pembilang $=2$ dan dk penyebut $=90$ pada taraf signifikansi $\alpha=0,05$ sebesar 3,09 dan pada taraf signifikansi $\alpha=$ 0,01 sebesar 4,82 maka diketahui bahwa $F_{\text {hitung }}>F_{\text {tabel }}$ yaitu $(36,249>3,09)$ sehingga dapat

disimpulkan bahwa persamaan regresi berganda $\hat{\mathrm{Y}}=89,935+0,333 \mathrm{X}_{1}+0,174 \mathrm{X}_{2}$ dapat digunakan sebagai acuan untuk memprediksi adanya hubungan Inovasi Guru melalui Budaya Organisasi dan Kompetensi Pedagogik secara bersama-sama.

Hasil uji signifikansi koefisien korelasi menggunakan Uji $\mathrm{F}$ dengan kriteria jika $\mathrm{F}_{\text {hitung }}>$ $F_{\text {tabel }}$ maka dinyatakan sangat signifikan. Hasil perhitungan uji signifikansi koefisien korelasi menghasilkan nilai $F_{\text {hitung }}$ sebesar 36,249 dengan nilai $F_{\text {tabel }}$ pada $\alpha=0,05$ sebesar 3,09 dan pada $\alpha=0,01$ sebesar 4,82 Dengan demikian diketahui bahwa $F_{\text {hitung }}>F_{\text {tabel }}$ yaitu (36,249>3,09), sehingga dapat disimpulkan bahwa koefisien korelasi variabel Budaya Organisasi $\left(\mathrm{X}_{1}\right)$ dan Kompetensi Pedagogik $\left(\mathrm{X}_{2}\right)$ secara bersama-sama dengan variabel Inovasi Guru (Y) dinyatakan sangat signifikan. 


\section{Uji Korelasi Parsial}

Analisis korelasi parsial dilakukan antara variabel $\mathrm{Y}$ dengan variabel $\mathrm{X}_{2}$ dalam kondisi variabel $\mathrm{X}_{1}$ dikontrol (tetap). Hasil perhitungan memperoleh besaran $r_{y 2-1}$ sebesar 0,177 . Uji signifikansi koefisien korelasi parsial $r_{y 2-1}$ menggunakan statistik uji " $t$ " dan memperoleh hasil $t_{\text {hitung }}$ sebesar 3,238. Besaran ini dikonsultasikan $t_{\text {tabel }}$ dalam taraf nyata alpha 0,01 ; diperoleh besaran $t$ sebesar 2,617 atau $t_{\text {hitung }}>t_{\text {tabel }}$. Dengan demikian koefisien korelasi parsial dapat dinyatakan sangat signifikan. Artinya Kompetensi Pedagogik memberikan kontribusi yang berarti terhadap peningkatan Inovasi Guru.

\section{PEMBAHASAN}

\section{Hubungan Variabel Budaya Organisasi $\left(X_{1}\right)$ dengan Variabel Inovasi Guru $(Y)$}

Pengujian hipotesis pertama menyimpulkan bahwa terdapat hubungan positif yang sangat signifikan antara Budaya Organisasi dengan Inovasi Guru yang ditunjukkan oleh nilai $\mathrm{t}_{\text {hitung }}$ sebesar 8,252 jauh lebih besar dari pada nilai $\mathrm{t}_{\text {tabel }}$ pada taraf signifikansi alpha 0,01 yaitu 2,617 atau 8,252 > 2,617. Pola hubungan antara kedua variabel ini dinyatakan oleh persamaan regresi $\hat{Y}=96,249+0,321 X_{1}$. Persamaan ini memberikan informasi bahwa setiap perubahan satu tingkat Budaya Organisasi akan dapat mengakibatkan terjadinya perubahan Inovasi Guru sebesar 0,321 pada konstanta 96,249.

Hasil analisis korelasi sederhana antara Budaya Organisasi dengan Inovasi Guru diperoleh nilai koefisien korelasi $r_{\mathrm{y} 1}$ sebesar 0,654 . Nilai ini memberikan pengertian bahwa keterkaitan antara Budaya Organisasi dengan Inovasi Guru kuat dan positif, artinya makin baik Budaya Organisasi makin tinggi pula Inovasi Guru tersebut. Demikian pula sebaliknya, makin kurang baik Budaya Organisasi, makin rendah pula Inovasi Gurunya.

Temuan penelitian ini sejalan dengan temuan penelitian Afyani tahun 2013 yang menyatakan bahwa budaya organisasi berpengaruh terhdap keinovatifan guru. Sejalan juga dengan teori dari Jones (2012:24-25) yang menyatakan bahwa budaya organisasi sanga penting dalam menumbuhkan keinovatifan guru

\section{Hubungan Variabel Kompetensi Pedagogik $\left(\mathbf{X}_{2}\right)$ dengan Variabel Invoasi Guru (Y)}

Pengujian hipotesis kedua menyimpulkan bahwa terdapat hubungan positif yang sangat signifikan antara Kompetensi Pedagogik dengan Inovasi Guru yang ditunjukkan oleh nilai $t_{\text {hitung }}$ sebesar 3,238 jauh lebih besar dari pada nilai $t_{\text {tabel }}$ pada taraf signifikansi alpha 0,01 yaitu 2,617 atau $t=3,238>2,617$. Pola hubungan antara kedua variabel ini dinyatakan oleh persamaan regresi $\hat{Y}=146,719+0,032 X_{2}$. Persamaan ini memberikan informasi bahwa setiap perubahan satu unit skor Kompetensi Pedagogik akan mengakibatkan terjadinya perubahan skor Inovasi Guru sebesar 0,032 pada konstanta 146,719.

Hasil analisis korelasi sederhana antara Kompetensi Pedagogik dengan Inovasi Guru diperoleh nilai koefisien korelasi $r_{\mathrm{y} 2}$ sebesar 0,025 . Nilai ini memberikan pengertian bahwa keterkaitan antara Kompetensi Pedagogik dengan Inovasi Guru kuat dan positif, artinya makin tinggi Kompetensi Pedagogik akan makin tinggi pula Inovasi Guru tersebut. Demikian pula sebaliknya, makin rendah Kompetensi Pedagogik, makin rendah pula Inovasi Guru tersebut.

Temuan penelitian ini sejalan dengan temuan penelitian Soebandi tahun 2012 yang menyatakan bahwa budaya organisasi berpengaruh terhdap keinovatifan guru. Sejalan juga dengan teori dari Thalib (2010:275) yang menyatakan bahwa budaya organisasi sanga penting dalam menumbuhkan keinovatifan guru 
3. Hubungan Variabel Budaya Organisasi $\left(X_{1}\right)$ dan Variabel Kompetensi Pedagogik $\left(X_{2}\right)$ dengan Variabel Inovasi Guru (Y)

Pengujian hipotesis menyimpulkan terdapat hubungan positif yang sangat signifikan antara Budaya Organisasi dan Kompetensi Pedagogik secara bersama-sama dengan Inovasi Guru yang ditunjukkan oleh nilai $F_{\text {hitung }}$ sebesar 36,249. Pola hubungan dinyatakan oleh persamaan regresi ganda $\hat{\mathrm{Y}}=89,935+0,333 \mathrm{X}_{1}+0,174 \mathrm{X}_{2}$. Persamaan ini memberikan informasi bahwa setiap perubahan satu unit skor Budaya Organisasi dan Kompetensi Pedagogik akan mengakibatkan terjadinya perubahan Inovasi Guru sebesar 0,333 atau 0,174.

Hasil analisis korelasi ganda antara Budaya Organisasi dan Kompetensi Pedagogik diperoleh nilai koefisien korelasi ganda sebesar $r_{\mathrm{y} .12}$ sebesar 0,664. Nilai ini menunjukkan bahwa keterkaitan antara Budaya Organisasi dan Kompetensi Pedagogik secara bersamasama dengan Inovasi Guru sangat kuat dan positif.

Dengan demikian berarti makin baik Budaya Organisasi dan makin tinggi Kompetensi Pedagogik seorang guru, makin tinggi pula Inovasi Guru. Sebaliknya makin kurang baik Budaya Organisasi makin rendah Kompetensi Pedagogik seorang guru, makin rendah pula Inovasi Guru.

\section{SIMPULAN}

Terdapat hubungan positif dan sangat signifikan antara budaya organisasi dengan inovasi guru. Ini berarti bahwa budaya organisasi memberikan kontribusi terhadap inovasi guru. Terdapat hubungan positif dan sangat signifikan antara kompetensi pedagogik dengan inovasi guru. Ini berarti bahwa kompetensi pedagogik memberikan kontribusi terhadap inovasi guru. Terdapat hubungan positif dan sangat signifikan antara Budaya Organisasi dan Kompetensi Pedagogik secara bersama-sama dengan Inovasi Guru. Ini berarti bahwa budaya organisasi dan kompetensi pedagogik secara bersama-sama mempunyai kontribusi terhadap inovasi guru.

\section{DAFTAR PUSTAKA}

E. Mulyasa. 2007. Menjadi Guru Profesional menciptakan Pembelajaran Kreatif dan Menyenangkan. Bandung : Rosdakarya.

Farida Sarimaya. 2008. Sertifikasi Guru, Apa, Mengapa dan Bagaimana?, Bandung: Penerbit Yrama Widya.

Garcia, R., and R. Calantone. 2002. “A Critical Look at Technological Innovation Typology and Innovativeness Terminology: A Literature Review. The Journal of Product Innovation Management, Vol. 19, pp. 110-132.

George, Jennifer M. and Gareth R. Jones. 2012. Understanding and Managing Organizational Behavior, Upper-Saddle River, NJ: Prentice-Hall.

Hadari Nawawi, 2003. Kepemimpinan Mengefektifkan Organisasi, Yogyakarta: Gadjah Mada University Press.

Muhajir Darwin, 2004. Teori Organisasi, Jakarta: Pustaka Pelajar.

Popi Sopiatin. 2010. Manajemen Belajar Berbasis Kepuasan Siswa, Bogor: Ghalia Indonesia. 
Robbin, Stephen P. and Timothy A. Judge. 2013. Organizational Behavior, New York: Pearson Education.

Rogers, Everett M \& Rekha Agrawala-Rogers. 2006. Communication in organization. New York: The Free Press.

Sjafrie Mangkuprawira, 2007. Budaya organisasi, Jakarta: Gramedia.

Stogdill, Ralph M. 2004. Handbook of Leadership, London: Collier Macmillian Publisher. Suwarto, 2002. Efektivitas Organisasi: Kajian Perilaku, Jakarta: Erlangga.

Syamsul Bachri Thalib. 2010. Psikologi Pendidikan Berbasis Analisis Empiris Aplikatif. Jakarta: Kencana.

Uhl-Bien, Mary, John R. Schermerhorn, Jr., and Richard N. Osborn, 2014. Organizational Behavioral, New York John Wiley \& Sons. 